\title{
Evidence for T Cell-dependent Immunity to Bacteroides fragilis in an Intraabdominal Abscess Model
}

\author{
Andrew B. Onderdonk, Richard B. Markham, Dori F. Zaleznik, \\ Ronald L. Cisneros, and Dennis L. KaSPER, Infectious Disease Research \\ Laboratory, Tufts University Schools of Veterinary Medicine and Medicine, \\ Boston, Massachusetts, 02115; Division of Infectious Diseases, Beth Israel \\ Hospital and, Channing Laboratory, Brigham and Women's Hospital, \\ Harvard Medical School, Boston, Massachusetts 02115
}

A B S T RACT It has been shown that active immunization of rats with the capsular polysaccharide of Bacteroides fragilis protects these animals against abscess development following intraperitoneal challenge with this species. Passive transfer of hyperimmune globulin from immunized animals to nonimmune recipients provided protection against $B$. fragilis bacteremia in challenged animals, but did not confer protection against abscess development. On the other hand, adoptive transfer of spleen cells from immunized animals to nonimmunized recipients resulted in protection against abscesses following challenge with $B$. fragilis. These data suggested that a $T$ cell-dependent immune response was involved in protection against abscess development after immunization with $B$. fragilis capsular antigen.

To determine the possible role of cell-mediated immunity prompted by the capsular antigen, inbred congenitally athymic OLA/Rnu rats and their phenotypically normal littermates were actively immunized. Despite the development of high titers of anti-B. fragilis capsular antibody, $100 \%$ of actively immunized athymic rats developed abscesses, as did $100 \%$ of unimmunized athymic control rats. However, no phenotypically normal littermate control rats that were actively immunized developed abscesses, while $100 \%$ of phenotypically normal unimmunized rats developed abscesses. Additional studies showed that adoptive transfer of $T$ cell-enriched spleen cell preparations

Dr. Kasper is the recipient of Research Career Development Award No. 1 K04 AI00126 from the National Institutes of Allergy and Infectious Diseases. Dr. Markham is the recipient of a Burroughs-Wellcome Fellowship of the Infectious Diseases Society of America. Address reprint requests to Dr. A. B. Onderdonk, Jamaica Plains, Mass. 02130.

Received for publication 8 December 1980 and in revised form 8 September 1981. from Wistar/Lewis rats immunized with the capsular polysaccharide to nonimmune recipients also resulted in protection against $B$. fragilis-induced abscesses.

We conclude that the protection afforded by immunization with $B$. fragilis capsule against intraabdominal abscesses caused by that organism is $T$ cellmediated and does not require the presence of serum antibody.

\section{INTRODUCTION}

Among the obligate anaerobes, Bacteroides fragilis is the species most commonly isolated from a variety of clinical sources, including blood cultures $(1,2)$. B. fragilis is also an important component for intraabdominal abscess formation in an experimental animal model (3-5). It has been shown that $B$. fragilis strains contain an antigenically common capsular antigen not found on other phenotypically similar species of Bacteroides (B. distasonis, B. vulgatus, B. thetaiotaomicron, and $B$. ovatus) $(6,7)$. The relationship of this capsular material to virulence was clarified by the observations that of the various Bacteroides species examined only $B$. fragilis, when implanted into the peritoneal cavity of rats with $\mathrm{BaSO}_{4}$ and sterile cecal contents, was capable of causing abscesses in the absence of other bacteria. Implantation of the capsular polysaccharide $(\mathrm{CP})^{1}$ of $B$. fragilis without viable bacteria also resulted in abscess formation in this model (4). Subsequent experiments revealed that animals immunized with $B$. fragilis capsular antigen before intraperitoneal challenge developed significant rises in serum antibody concentration to the capsular antigen. These actively immunized animals were protected

\footnotetext{
${ }^{1}$ Abbreviations used in this paper: CFU, colony-forming units; $\mathrm{CP}$, capsular polysaccharide; $\mathrm{PD}_{50}, 50 \%$ protective dose.
} 
from development of abscesses when challenged with $B$. fragilis but were not protected against abscess development when challenged with a bacteriologically complex fecal inoculum. However, $B$. fragilis was not part of the microflora isolated from abscesses in immunized recipients who had been challenged with the fecal material, despite the presence of $B$. fragilis in the fecal inoculum. In addition, the early bacteremia with $B$. fragilis noted in nonimmunized animals did not occur in immunized animals (8).

The present report analyzes the immunological basis for the protection conferred in the rat model by immunization with the $B$. fragilis capsule. Specifically we have found that abscess development can only be prevented in rats with intact $\mathrm{T}$ lymphocyte function and that protection against abscesses can be adoptively transferred with immune $T$ cell-enriched populations, but not with immune serum, nor B cell- and macrophage-enriched populations. Immune serum did protect against bacteremia, indicating that protection against all the manifestations of $B$. fragilis infection, which is achieved after active immunization with capsular material, involves both humoral and cell-mediated immunity.

\section{METHODS}

Animals. Two inbred strains of rats were used during these studies. Wistar/Lewis rats were obtained from Charles River Breeding Laboratories (Wilmington, Mass.). Congenitally athymic OLA/Rnu rats homozygous for the athymic trait and their phenotypically normal littermates, heterozygous for the athymic trait were also used (Olac, Ltd., England). Male animals weighing $120 \mathrm{~g}$ were used for immunization protocols. At the time of bacterial challenge, animals weighed $180-200 \mathrm{~g}$. Animals were maintained two per cage, in stainless steel cages, with the exception of OLA/ Rnu athymic animals. These rats were housed in plastic cages equipped with filter bonnets and were fed sterile chow and water. Other animals were maintained on chow (Agway Inc., Syracuse, N. Y.) and water ad lib.

Bacterial strains. Cultures of B. fragilis (American Type Culture Collection, ATCC 23745) and B. distasonis (ATCC 8503) were obtained from the stock culture collection of the Channing Laboratory, Boston, Mass. Cultures of Fusobacterium varium (TVDL3) and enterococcus (TVDL41) were obtained from the stock culture collection of the Tufts University Veterinary Diagnostic Laboratory, Boston, Mass. All cultures were grown in prereduced peptone yeast glucose medium (Scott Laboratories, Fiskeville, R.I.) within an anaerobic isolator (Lab-Line Instruments, Melrose Park, Ill.) for 24-48 h. Following incubation cultures were divided into $5-\mathrm{ml}$ aliquots, placed into gas tight vials, and frozen at $-70^{\circ} \mathrm{C}$ until used.

Study design. Experiments were divided into 19 groups based on the type of immunization and the strain of animals (Table I). Animals were bled before immunization and subsequently were given 3 i.m. injections a week for $3 \mathrm{wk}$ and a booster injection in the 4th wk. 5 wk after immunization was initiated, animals were either implanted with one of the bacterial inocula, exsanguinated for hyperimmune sera, or splenectomized. Postimmunization sera were obtained at the time of implantation. Groups receiving spleen cells were lightly anesthetized with ether $24 \mathrm{~h}$ before challenge and given $1.0 \mathrm{ml}$ of a spleen cell preparation by the intracardiac route. Animals receiving hyperimmune globulin were given $0.5 \mathrm{ml}$ of the globulin preparation intracardiac, at the time of implantation. All animals weighed between 180 and 200 $\mathrm{g}$ at the time of surgical implantation of the bacterial challenge. $7 \mathrm{~d}$ after challenge, all animals were killed and examined for the presence or absence of intraabdominal abscesses.

\section{Immunization}

The preparation of the antigens used for these studies and the immunization regimen have been described previously (8). Briefly, animals were given i.m. injections of $10 \mu \mathrm{g}$ of B. fragilis CP in $0.1 \mathrm{ml}$ phosphate-buffered saline.

Immune globulin. Gamma globulin was prepared from pooled sera obtained from rats immunized with the $B$. fragilis capsule $(9,10)$.

Serologic methods. Preimmunization sera and sera obtained at the time of bacterial challenge were tested. Antibody to the $B$. fragilis capsular antigen was quantitated by the radioactive antigen binding assay described previously (9).

Preparation of spleen cells. Spleens were removed from immunized animals $5 \mathrm{wk}$ after beginning immunization and placed into $20 \mathrm{ml}$ of sterile Hanks' balanced salt solution at room temperature. The spleens were minced with sterile scissors and cells released by gentle disruption of the tissues on a stainless steel wire gauze. The cell preparation was filtered through sterile glass wool to remove cell clumps and then assayed for total cell density and viable cell density using manual counting methods and trypan blue exclusion. The viable cell density was routinely $85-90 \%$ of the total cell density. Following viability determinations, cell preparations were diluted appropriately with sterile Hanks' balanced salt solution. The final preparations were immediately injected into nonimmunized rats by the intracardiac route. The mortality rate for this procedure was $<5 \%$ with all deaths occurring within 5 min of injection.

Nylon wool column methods. Separation of $\mathrm{T}$ and B cells from the rat spleen was performed using nylon wool columns. It is known that B cells and macrophages generally adhere to nylon wool, while $\mathrm{T}$ and null cells pass through. The methods used were those published by Julius et al. (11). $35-\mathrm{cm}^{3}$ syringe columns were set up with 3-way stopcocks and 18-gauge needles. $50 \mathrm{~cm}^{3}$ of balanced salt solution with $5 \%$ fetal calf serum, which was used as the media throughout, was run through the column. Spleens were removed from immunized rats and cells released by disruption with a stainless steel wire mesh gauze. The cells were passed through a dacron gauze filter to remove debris and counted using a Coulter Fn counter (Coulter Electronics Inc., Hialeah, Fla.). $3 \times 10^{8}$ spleen cells were suspended in media to give a volume of $6 \mathrm{~cm}^{3}$. Cells were loaded onto the column and incubated at $37^{\circ}$ for $1 \mathrm{~h}$. Columns were eluted with $50 \mathrm{~cm}^{3}$ of media at $37^{\circ} \mathrm{C}$ with an elution rate of $1 \mathrm{drop} / \mathrm{s}$. Cells were spun at $1,000 \mathrm{rpm}$ for $15 \mathrm{~min}$, brought up in $6 \mathrm{~cm}^{3}$ balanced salt solution, like fractions pooled and counted in the Coulter counter. $50 \mathrm{~cm}^{3}$ of balanced salt solution at $4^{\circ} \mathrm{C}$ was run through the columns, again at the rate of $1 \mathrm{drop} / \mathrm{s}$. These fractions were also centrifuged, pooled and counted. Appropriate dilutions were made for cell transfer. 
TABLE I

Immunization Status, Bacterial Inoculum and Strains of Rats Used for Study

\begin{tabular}{|c|c|c|c|c|}
\hline Group & Immunogen & Type of immunization & Challenge inoculum & Strain \\
\hline $\mathbf{A}$ & None & None & B. distasonis plus enterococcus ${ }^{\circ}$ & Wistar/Lewis \\
\hline B & None & None & B. fragilis & Wistar/Lewis \\
\hline C & Hyperimmune globulin & Passive & B. distasonis plus enteroccus & Wistar/Lewis \\
\hline $\mathbf{D}$ & Hyperimmune globulin & Passive & B. fragilis & Wistar/Lewis \\
\hline $\mathbf{E}$ & B. fragilis $\mathrm{CP}$ & Active & B. fragilis & Wistar/Lewis \\
\hline $\mathbf{F}$ & B. fragilis CP & Active & F. varium plus enterococcus $\S$ & Wistar/Lewis \\
\hline G & None & None & B. fragilis & Wistar/Lewis \\
\hline $\mathbf{H}$ & None & None & $F$. varium plus enterococcus & Wistar/Lewis \\
\hline$I_{1,7}{ }^{\prime \prime}$ & $\begin{array}{l}\text { Spleen cells from im- } \\
\text { munized rats }\end{array}$ & Adoptive transfer & B. fragilis & Wistar/Lewis \\
\hline $\mathbf{J}$ & $\begin{array}{l}\text { Spleen cells from im- } \\
\text { munized rats }\end{array}$ & Adoptive transfer & F. varium plus enterococcus & Wistar/Lewis \\
\hline $\mathbf{K}$ & $\begin{array}{l}\text { Spleen cells from non- } \\
\text { immunized rats }\end{array}$ & Adoptive transfer & B. fragilis & Wistar/Lewis \\
\hline $\mathbf{L}$ & None & None & B. fragilis & OLA/Rnu normal \\
\hline $\mathbf{M}$ & B. fragilis CP & Active & B. fragilis & OLA/Rnu normal \\
\hline $\mathbf{N}$ & None & None & B. fragilis & OLA/Rnu athymic \\
\hline $\mathbf{O}$ & B. fragilis CP & Active & B. fragilis & OLA/Rnu athymic \\
\hline $\mathbf{P}$ & $\begin{array}{l}\text { Spleen cells from non- } \\
\text { immunized rats }\end{array}$ & Adoptive transfer & B. fragilis & Wistar/Lewis \\
\hline $\mathbf{Q}$ & $\begin{array}{l}\text { Spleen cells from im- } \\
\text { munized rats }\end{array}$ & Adoptive transfer & B. fragilis & Wistar/Lewis \\
\hline $\mathbf{R}$ & $\begin{array}{l}\mathrm{T} \text { cell enriched im- } \\
\text { mune spleen cells }\end{array}$ & Adoptive transfer & B. fragilis & Wistar/Lewis \\
\hline $\mathbf{S}$ & $\begin{array}{l}\text { B cell/macrophage en- } \\
\text { riched immune } \\
\text { spleen cells }\end{array}$ & Adoptive transfer & B. fragilis & Wistar/Lewis \\
\hline
\end{tabular}

- B. distasonis ATCC 8503 plus enterococcus TVDL 41

t B. fragilis ATCC 23745

$\$ F$. varium TVDL 3 plus enterococcus TVDL 41

"This group included animals implanted with organisms $1 \mathrm{~d}$ and $7 \mathrm{~d}$ after spleen cell transfer.

Preparation of bacterial challenge. Quantitative determinations of viable cell density were made by means of direct plate counts of each strain following freezing of the original culture preparations. Samples of each bacterial strain were thawed within an anaerobic chamber and serial 10-fold dilutions made using sterile dilution salts (12). Duplicate $0.1-\mathrm{ml}$ portions of each dilution were plated onto Brucella base blood agar and allowed to dry. Plates were incubated for $48 \mathrm{~h}$ at $37^{\circ} \mathrm{C}$ within an anaerobic chamber and colonies enumerated. Before implantation, bacterial cultures were diluted to the appropriate concentration with sterile peptone yeast glucose broth (5).

Challenge inocula. Three challenge inocula were prepared for implantation into rats. The first consisted of $1 \times 10^{8}$ colony-forming units (CFU)/ $\mathrm{ml}$ of $B$. fragilis (ATCC23745). The second inoculum consisted of $5 \times 10^{7} \mathrm{CFU} / \mathrm{ml}$ of $B$. distasonis (ATCC8503) and $5 \times 10^{7} \mathrm{CFU} / \mathrm{ml}$ enterococcus (TVDL41). The third inoculum consisted of $5 \times 10^{7} \mathrm{CFU} /$ $\mathrm{ml} F$. varium (TVDL3) and $5 \times 10^{7} \mathrm{CFU} / \mathrm{ml}$ enterococcus (TVDL41). All inocula contained $50 \% \mathrm{vol} / \mathrm{vol}$ cecal contents and $10 \% \mathrm{wt} / \mathrm{vol}$ barium sulfate as described previously (3).

Control experiments have shown that neither barium sul- fate nor cecal contents cause abscess formation by themselves, or in combination (3).

Implantation of inoculum. Before implantation, animals were anesthetized with $0.15 \mathrm{ml}(60 \mathrm{mg} / \mathrm{ml})$ of nembutal and blood obtained by percutaneous cardiac puncture from appropriate groups for determination of antibody levels to $B$. fragilis CP. Animals were shaved, prepped with betadine, and an anterior midline incision made through the skin and underlying musculature. A gelatin capsule containing $0.5 \mathrm{ml}$ of inoculum was inserted through the incision and then closed with interrupted 3-0 silk sutures (3).

Evaluation of results. $7 \mathrm{~d}$ after implantation, animals were killed and necropsied in a "blind" fashion so that the prosecutor was not aware of which group of animals was being necropsied. Abscesses were considered to be present if loculated collections containing purulent exudates were found, which showed polymorphonuclear leukocytes and bacteria when examined microscopically. Cultures from randomly selected animals were obtained to insure the presence of only the challenge bacterial species. Statistical comparisons of the various groups containing abscesses were made using $\chi^{2}$ analysis (13), while a comparison of antibody levels was made using a $t$ test for paired samples (14). 
TABLE II

Lack of Efficacy of Hyperimmune Globulin Prepared to the CP of B. fragilis in Protecting Rats against Challenge with Either B. fragilis or B. distasonis plus Enterococcus

\begin{tabular}{|c|c|c|c|c|c|c|}
\hline \multirow[t]{3}{*}{ Group } & \multirow[t]{3}{*}{ Inoculum } & \multirow[t]{3}{*}{ Immunogen } & \multicolumn{2}{|c|}{$\begin{array}{l}\text { Antibody } \\
\text { concentration to } \\
\text { the } B \text {. fragilis } \\
\text { capsule }\end{array}$} & \multirow[t]{2}{*}{$\begin{array}{c}\text { Abscess } \\
\text { incidence }^{\circ}\end{array}$} & \multirow[t]{3}{*}{ Abscess contents! } \\
\hline & & & \multicolumn{2}{|c|}{$\mu g$ of antibody $/ \mathrm{ml}$} & & \\
\hline & & & Pre & $72 h^{\circ}$ & & \\
\hline A & B. distasonis and enterococcus & None & - & - & $9 / 10$ & B. distasonis enterococcus \\
\hline B & B. fragilis & None & - & - & $10 / 10$ & B. fragilis \\
\hline $\mathrm{C}$ & B. distasonis and enterococcus & Hyperimmune globulin & $<4.0$ & 6.1 & $10 / 10$ & B. distasonis enterococcus \\
\hline D & B. fragilis & Hyperimmune globulin & $<4.0$ & 6.1 & $10 / 10$ & B. fragilis \\
\hline
\end{tabular}

- Number with abscesses/number of survivors.

† Similar results were obtained for all animals tested.

$\$ 72 \mathrm{~h}$ after transfer. Pre, preimmunization.

\section{RESULTS}

Efficacy of passive transfer of hyperimmune globulin. Challenge of animals receiving immune rat globulin before implantation with either $B$. distasonis plus enterococcus or $B$. fragilis (groups $C$ and D) did not result in any decrease in abscess incidence as compared to unimmunized controls (groups A and B, Table II). Interestingly, both groups $C$ and $D$ had measurable levels of antibody to $B$. fragilis CP that persisted for at least $72 \mathrm{~h}$. Bacteriologic cultures of abscess contents yielded only the implanted species. The inability to passively transfer immunity to abscesses caused by $B$. fragilis with hyperimmune globulin suggested that other factors were required for immunity, because active immunization (and increased antibody titers to B. fragilis CP) had been shown previously to be associated with protection in this model (8). Despite the appearance of abscesses in passively immunized animals receiving hyperimmune globulin, the early bacteremia with $B$. fragilis noted in nonimmunized animals was qualitatively and quantitatively reduced by passive transfer of hyperimmune globulin (Table III).
These data suggest that the immune factors responsible for protection in the abdominal cavity and in the blood are different, since passively transferred antibody reduces bacteremia but not abscess formation.

Efficacy of adoptive transfer of spleen cells. To determine whether host immune factors other than antibody were responsible for immunity to intraabdominal abscesses, animals were actively immunized with $B$. fragilis CP and spleen cells adoptively transferred to nonimmunized rats. The results of these experiments (Table IV) show that animals immunized with $B$. fragilis $\mathrm{CP}$ and challenged with $B$. fragilis were protected against abscess formation (group E), while similarly immunized animals challenged with F. varium plus enterococcus were not (group F).

Adoptive transfer of spleen cells from animals immunized with $B$. fragilis $\mathrm{CP}$ to nonimmunized recipients challenged with $B$. fragilis $1 \mathrm{~d}\left(\mathrm{I}_{1}\right)$ or $7 \mathrm{~d}\left(\mathrm{I}_{7}\right)$ later resulted in significant protection (groups $I_{1,7}, P<0.05$ ) as compared to nonimmunized controls (group G) or recipients of immune spleen cells who were challenged with $F$. varium plus enterococcus. The protection afforded by transfer of spleen cells from $B$. fragilis $\mathrm{CP}$

TABLE III

Comparison of Quantitative Blood Cultures from Rats Receiving Either Hyperimmune Globulin to B. fragilis CP or Normal Rat Globulin Subsequently Challenged with B. fragilis

\begin{tabular}{|c|c|c|c|c|c|}
\hline \multirow[t]{2}{*}{ Group } & \multirow[t]{2}{*}{$n$} & \multicolumn{4}{|c|}{$\begin{array}{l}\text { Mean CFU/ml } \\
\text { (No. rats with postiive blood cultures/total tested) }\end{array}$} \\
\hline & & $2 h$ & $8 h$ & $24 h$ & $48 h$ \\
\hline Normal globulin & 3 & $10^{3.98} \pm 1.9(3 / 3)$ & $10^{3.70 \pm 1}(3 / 3)$ & $10^{1.9 \pm 0.5}(2 / 2)$ & $10^{1.3}(1 / 2)$ \\
\hline Hyperimmune globulin & 4 & $10^{2.9 \pm 0.39}(4 / 4)$ & $10^{2.0 \pm 0.75}(3 / 4)$ & $0(0 / 3)$ & $0(0 / 2)$ \\
\hline & & $P<0.01^{\circ}$ & $P<0.001$ & $P<0.02$ & \\
\hline
\end{tabular}

- $P$ values determined based on CFU. 
TABLE IV

Efficacy of Active Immunization or Adoptive Transfer of Spleen Cells from Immunized Wistar/Lewis Rats against Challenge with B. fragilis or F. varium plus Enterococcus

\begin{tabular}{|c|c|c|c|c|c|}
\hline Group & Inoculum & Immunogen & Type of immunization & Abscess incidence ${ }^{\bullet}$ & Abscess contents \\
\hline $\mathbf{E}$ & B. fragilis 23745 & B. fragilis $\mathrm{CP}$ & Active & $0 / 5 \quad(<0.02) \S$ & - \\
\hline $\mathbf{F}$ & F. varium, enterococcus & B. fragilis $\mathrm{CP}$ & Active & $9 / 10(\mathrm{NS})$ & F. varium, enterococcus \\
\hline G & B. fragilis & None & None & $5 / 5$ & B. fragilis \\
\hline $\mathbf{H}$ & F. varium, enterococcus & None & None & $5 / 5$ & F. varium, enterococcus \\
\hline $\mathbf{I}_{1}$ & $\begin{array}{l}\text { B. fragilis } \\
\text { given } 1 \mathrm{~d} \text { after cell transfer }\end{array}$ & $\begin{array}{l}\text { Spleen cells from } \\
\text { immunized rats }\end{array}$ & Adoptive transfer & $2 / 8 \quad(<0.05)$ & B. fragilis \\
\hline $\mathbf{I}_{\boldsymbol{i}}$ & $\begin{array}{l}\text { B. fragilis } \\
\text { given } 1 \text { wk after cell transfer }\end{array}$ & $\begin{array}{l}\text { Spleen cells from } \\
\text { immunized rats }\end{array}$ & Adoptive transfer & $0 / 5 \quad(<0.02)$ & - \\
\hline $\mathrm{J}$ & $F$. varium, enterococcus & $\begin{array}{l}\text { Spleen cells from } \\
\text { immunized rats }\end{array}$ & Adoptive transfer & $9 / 10(\mathrm{NS})$ & F. varium, enterococcus \\
\hline $\mathbf{K}$ & B. fragilis & $\begin{array}{l}\text { Spleen cells from } \\
\text { nonimmunized rats }\end{array}$ & Adoptive transfer & $9 / 10(\mathrm{NS})$ & B. fragilis \\
\hline
\end{tabular}

- Number with abscesses/number of survivors.

† Similar results were obtained for all animals.

$\S P$ value compared with incidence of abscesses in immunized controls.

immunized animals appears to be specific for $B$. fragilis, since challenge of spleen cell recipient animals with $F$. varium plus enterococcus resulted in abscesses (Group J). Additionally, spleen cells transferred from nonimmunized animals to nonimmunized recipients (group K) did not afford any protection to challenge with $B$. fragilis indicating that prior immunization of the donor was a requirement for protection.

These results indicated that specific protection against $B$. fragilis-induced abscess could be conferred by adoptive transfer of spleen cells from animals immunized with CP of $B$. fragilis. Measurement of serum antibody to the CP at the time of challenge in these recipients showed no substantial increase in antibody levels over pretransfer levels, indicating that serum antibody was not likely to be a factor in the protection. Moreover, the ability to transfer protection with spleen cells from immunized animals suggested that protection against $B$. fragilis-induced intraabdominal abscesses was $T$ cell-dependent.

Efficacy of active immunization in athymic rats. Active immunization of both OLA/Rnu normal and athymic animals resulted in increased levels of serum antibody to $B$. fragilis $\mathrm{CP}$ (Table $\mathrm{V}$, groups $\mathrm{M}$ and $\mathrm{O}$ ). These sera were taken at the time of necropsy. Despite increased levels of antibody, only the OLA/Rnu normal animals were protected from $B$. fragilis-induced abscesses $(P<0.05)$ as compared with nonimmunized controls (groups L and N) or immunized OLA/Rnu athymic animals. The presence of higher antibody levels in the immunized athymic rats compared with the nonimmunized athymic animals might be interpreted to indicate that the response was primarily a result of polysaccharide immunization as opposed to bacterial

TABLE V

Efficacy of Active Immunization of Athymic Rats with B. fragilis CP against Challenge with B. fragilis

\begin{tabular}{|c|c|c|c|c|c|c|}
\hline Group & Inoculum & Rat strain & Immunogen & $\begin{array}{c}\text { Antibody concentration } \\
\text { to the } B \text {. fragilis } \\
\text { capsule }\end{array}$ & $\begin{array}{c}\text { Number } \\
\text { with } \\
\text { abscess/total }\end{array}$ & $\begin{array}{c}\text { Abscess } \\
\text { contentst }\end{array}$ \\
\hline $\mathrm{L}$ & B. fragilis & OLA/Rnu normal & None & $7.8 \pm 1$ & $5 / 5$ & B. fragilis \\
\hline $\mathbf{M}$ & B. fragilis & OLA/Rnu normal & B. fragilis $\mathrm{CP}$ & $6.4 \pm 1$ & $0 / 5 \S$ & - \\
\hline $\mathbf{N}$ & B. fragilis & OLA/Rnu athymic & None & $<4.0$ & $4 / 4$ & B. fragilis \\
\hline $\mathbf{O}$ & B. fragilis & OLA/Rnu athymic & B. fragilis $\mathrm{CP}$ & $8.5 \pm 1.7$ & $9 / 9$ & B. fragilis \\
\hline
\end{tabular}

- Mean \pm SD at time of necropsy; preimmunization $<4.0 \mu \mathrm{g} / \mathrm{ml}$.

t Similar results were obtained for all animals.

$\S P<0.5$ ( $P$ value compares incidence of abscesses in normal immunized rats with immunized athymic rats. 
challenge. These data indicate that in this animal species the presence of $T$ cell-mediated immune response to the CP of $B$. fragilis is necessary for prevention of the intraabdominal abscesses.

Efficacy of transfer of $T$ cell-enriched spleen cell populations. Previous experiments showed that protection occurred when spleen cells from immune animals were adoptively transferred to nonimmune recipients challenged with $B$. fragilis. To better define the cell populations involved, $T$ cell-enriched populations were obtained from immune spleen cells by separation on nylon wool columns. This method generally gave a yield of $1.1 \times 10^{7}$ cells $/ \mathrm{ml}(22 \%)$ with warm $\left(37^{\circ} \mathrm{C}\right)$ elution. This is consistent with previously published data for cell yields using nylon wool columns (11). Cold elution $\left(4^{\circ} \mathrm{C}\right)$, which elutes $B$ cells and macrophages adherent during warm elution, yielded 1.6 $\times 10^{6}$ cells $/ \mathrm{ml}$. Transfer of these T cell-enriched and $B$ cell and macrophage populations to nonimmune recipients (groups $\mathrm{P}-\mathrm{S}$, Table VI) indicate that significant protection against abscess development occurs when immune $\mathrm{T}$ cell-enriched populations are transferred. B cell- and macrophage-enriched populations from the same spleens failed to transfer immunity to nonimmune recipients challenged with $B$. fragilis. The $50 \%$ protective dose $\left(\mathrm{PD}_{50}\right)$ for $\mathrm{T}$ cell enriched transfer recipients was $3.2 \times 10^{5}$ cells, while the $\mathrm{PD}_{50}$ for the B cell and macrophage recipients was $>2 \times 10^{6}$ cells.

TABLE VI

Efficacy of Adoptive Transfer of T Cell-enriched or B Cell and Macrophage Populations from Immunized Wistar/Lewis Rats against Challenge with $B$. fragilis

\begin{tabular}{|c|c|c|c|}
\hline Group & Immunogen & $\begin{array}{c}\text { Cell } \\
\text { density }\end{array}$ & $\begin{array}{c}\text { Abscess } \\
\text { Incidencet \$ }\end{array}$ \\
\hline $\mathbf{P}$ & Spleen cells from unimmunized rats & $2.5 \times 10^{6}$ & $10 / 10$ \\
\hline Q & $\begin{array}{l}\text { Spleen cells from rats immunized } \\
\text { with } B \text {. fragilis capsular polysac- } \\
\text { charide }\end{array}$ & $\begin{array}{l}2.5 \times 10^{6} \\
8 \times 10^{5} \\
4 \times 10^{5} \\
2.5 \times 10^{5}\end{array}$ & $\begin{array}{l}0 / 9 \\
1 / 5 \\
2 / 5 \\
3 / 3\end{array}$ \\
\hline $\mathbf{R}$ & $\begin{array}{l}\text { T cell-enriched spleen cells from } \\
\text { rats immunized with } B \text {. fragilis } \\
\text { capsular polysaccharide }\end{array}$ & $\begin{array}{l}2.5 \times 10^{6} \\
8.0 \times 10^{5} \\
4.0 \times 10^{5} \\
2.5 \times 10^{5}\end{array}$ & $\begin{array}{l}1 / 10 \\
1 / 5 \\
2 / 5 \\
3 / 4\end{array}$ \\
\hline $\mathbf{S}$ & $\begin{array}{l}\text { B cell- and macrophage-enriched } \\
\text { spleen cells from rats immunized } \\
\text { with } B \text {. fragilis }\end{array}$ & $\begin{array}{l}2 \times 10^{6} \\
8 \times 10^{5} \\
4 \times 10^{5}\end{array}$ & $\begin{array}{l}3 / 5 \\
4 / 5 \\
3 / 4\end{array}$ \\
\hline
\end{tabular}

- Viable cell density transferred to nonimmune recipients.

$\downarrow$ Comparison of total group $\mathrm{R}$ to group $\mathrm{S}$, chi-square analysis. ( $P$ $<0.01)$

$\S$ Protective dose for $50 \%$ of animals calculated by Reed-Muensch method. Group Q PD PD $=3.5 \times 10^{5}$ cells, Group R PD $_{50}=3.2$ $\times 10^{5}$ cells and Group S $\mathrm{PD}_{50}>2 \times 10^{6}$ cells.
A chi square comparison of the $T$ cell recipient and $B$ cell and macrophage recipient groups for protection against abscess regardless of the number of cells transferred was significant with a $P<0.01$.

\section{DISCUSSION}

Previous studies using the rat as a model for anaerobic infection have shown that challenge of animals with $B$. fragilis results in intraabdominal abscess formation. The propensity for the host to form abscesses when challenged with obligate anaerobes as opposed to the acute septicemia and mortality associated with the implantation of coliforms such as Escherichia coli clearly suggests that the host response is dependent upon the bacterial inoculum used. In this model it has been shown that $B$. fragilis strains by themselves are capable of causing abscesses and even the CP of $B$. fragilis alone potentiates abscess formation. The unique nature of the host response to a specific bacterial challenge suggests that immunity to this challenge may also be by different mechanisms. Previous studies (8) have shown that active immunization of rats with the $C P$ of $B$. fragilis results in protection against abscess development when challenged with either homologous or heterologous $B$. fragilis strains. This protection was shown to be specific for $B$. fragilis or related species, but did not protect against abscess formation when a complex mixture of fecal microflora was used. However, it was found that $B$. fragilis was eliminated from the infecting microflora. Protection in rats was shown to correlate with increased concentrations of serum antibody to the CP. In addition, immunized animals had reduced numbers of organisms during the early bacteremia associated with $B$. fragilis as compared with nonimmunized controls.

In the present experiments, passive transfer of hyperimmune globulin from rats immunized with the $C P$ of $B$. fragilis to nonimmunized animals did not result in protection against induced abscesses. The antibody levels measured in these animals were in the lower but elevated range. Actively immunized animals with similar levels of antibody were universally protected from abscess development. These results indicate that failure of antibody to protect against abscess development when passively transferred is not due to inadequate levels. However, protection against the early bacteremia associated with $\boldsymbol{B}$. fragilis was conferred by passive transfer of antibody when compared with nonimmunized animals.

Because active immunization was protective, a series of experiments were conducted to examine the mechanism involved in immunity induced by the capsule to intraabdominal abscesses. It was shown that the immunity to $B$. fragilis-induced abscesses could be adop- 
tively transferred with spleen cells from immunized animals to nonimmune recipients. Recipient animals did not show an increase in serum antibody as a result of spleen cell transfer, however, recipient animals were protected from abscess development when implanted with $B$. fragilis. Immunity in spleen cell recipients was specific for $B$. fragilis, since abscesses were noted in spleen cell recipients challenged with a combination of $F$. varium and enterococci. In addition, spleen cell transfer from nonimmune animals did not confer protection, indicating that protection is not due to nonspecific stimulation. Additionally, recipients given spleen cells and challenged with $B$. fragilis $7 \mathrm{~d}$ later were protected from abscess development. These transfer experiments suggest that two different immune mechanisms to $B$. fragilis challenge can be transferred from immunized to nonimmunized animals: serum antibody appears to transfer immunity to $B$. fragilis bacteremia, while spleen cells from immunized animals confers protection against intraabdominal abscess formation.

In an effort to identify the cell type passed with spleen cells that was responsible for immunity, congenitally athymic animals were immunized with $B$. fragilis $\mathrm{CP}$ and challenged with $B$. fragilis. Despite the presence of serum antibody at levels routinely associated with protection in immunologically normal rats, all recipients developed intraabdominal abscesses. On the other hand, phenotypically normal heterozygous littermates did not develop abscesses when challenged after immunization. It appears as if the protective response in these animals was $T$ cell-dependent. While certain $T$ cell functions have been shown to be inducible in athymic mice (15), any defects in the immune response have been shown to be due to the absence of $T$ cells. Clearly, the absence of $T$ cells in athymic rats results in a lack of protection against $B$. fragilis-induced abscesses, despite the presence of serum antibody. Proof of this fact was obtained by additional experiments in which $\mathrm{T}$ cell-enriched and B cell/macrophage populations obtained from the spleens of immunized animals were transferred to nonimmune recipients. These experiments revealed that $T$ cell recipients were protected against $B$. fragilisinduced abscesses but $B$ cell and macrophage recipients were not. These data indicate that immunity to $B$. fragilis-induced intraabdominal abscesses is $\mathrm{T}$ celldependent.

T cell-dependent immunity to bacterial antigens is not unique to $B$. fragilis. Immunity to both Mycobacterium tuberculosis $(15,16)$ and Listeria monocytogenes $(17,18)$ has been shown to be $T$ cell-dependent, and interestingly, another abscess producing organism, Staphylococcus aureus, has also been shown to elicit delayed hypersensitivity in mice (19). The effector mechanism by which $\mathrm{T}$ cell-dependent immunity against $B$. fragilis-induced abscesses operates has yet to be defined. Most human sera tested contain detectable antibody to $B$. fragilis (2), yet virtually all patients exposed to fecal contamination develop intraabdominal abscesses when antibiotic therapy fails to include coverage against anaerobes (20). The majority of such infections yield $B$. fragilis when cultured (21). These data indicate that the presence of circulating antibody to the surface antigen may not serve as a useful predictive measure for $B$. fragilis-induced abscesses. An important supporting clinical observation suggesting the importance of $\mathrm{T}$ cell-dependent immunity is a recent report of the association of $B$. fragilis with postappendectomy infections in profoundly lymphocytopenic patients (22).

A considerable body of evidence indicates that polysaccharides are able to elicit antibody response in research animals and man. B. fragilis $\mathrm{CP}$ is capable of functioning as a $T$-independent antigen in the classical manner of other polysaccharides as demonstrated by the ability of this antigen to stimulate antibody in athymic rats. There is much less evidence to support the concept that these antigens can stimulate a $T$ celldependent response, although reports of induction of such responses do exist (23-25). The antigen used for immunization in the current studies is a polysaccharide and contains no detectable protein. The secondary structure of this polysaccharide has not been determined.

From these studies it is apparent that both the cellular and humoral limbs of the immune system play important roles in protection against $B$. fragilis infection. As would be expected, antibody protects against bacteremia with these encapsulated bacteria. However, the distinctive pathological marker of $B$. fragilis infections is abscess formation and these studies indicate that $\mathrm{T}$ cell-dependent immunity protects against that process in this experimental model.

\section{ACKNOWLEDGEMENT}

The authors wish to thank Ms. Barbara G. Reinap for technical assistance and Ms. Loreen Carr for assistance in preparation of the manuscript.

This research was supported in part by contracts No. DAMD-17-74C-4056 and DAMD-17-7S-C-8019 from the U. S. Army Medical Research and Development Command.

\section{REFERENCES}

1. Wilson, W. R., J. W. Martin, C. J. Kowske, and J. A. Washington. 1972. Anaerobic bacteremia. Mayo Clin. Proc. 47: 639-646.

2. Polk, B. F., and D. L. Kasper. 1977. Bacteroides fragilis subspecies in clinical isolates. Ann. Intern. Med. 86: 569571 . 
3. Weinstein, W. M., A. B. Onderdonk, J. G. Bartlett, and S. L. Gorbach. 1974. Experimental intra-abdominal abscesses in rats: development of an experimental model. Infect. Immun. 10: 1250-1255.

4. Onderdonk, A. B., D. L. Kasper, R. L. Cisneros, and J. G. Bartlett. 1977. The capsular polysaccharide of $B$. fragilis as a virulence factor: comparison of pathogenic potential of encapsulated and unencapsulated strains. $J$. Infect. Dis. 136: 82-89.

5. Onderdonk, A. B., J. G. Bartlett, T. J. Louie, N. SullivanSiegler, and S. L. Gorbach. 1976. Microbial synergy in experimental intraabdominal abscess. Infect. Immun. 13: $22-26$.

6. Kasper, D. L. 1976. Chemical and biological characterization of the lipopolysaccharide of Bacteroides fragilis subspecies fragilis. J. Infect. Dis. 134: 59-66.

7. Kasper, D. L. 1976. The polysaccharide capsule of Bacteroides fragilis subspecies fragilis: immunochemical and morphologic definition. J. Infect. Dis. 134: 59-66.

8. Kasper, D. L., A. B. Onderdonk, J. Crabb, and J. G. Bartlett. 1979. Protective efficacy of immunization with capsular antigen against experimental infection with Bacteroides fragilis. J. Infect. Dis. 140: 724-731.

9. Kasper, D. L., A. B. Onderdonk, and J. G. Bartlett. 1978. Quantitative determination of the antibody response to the capsular polysaccharide of Bacteroides fragilis in an animal model of intraabdominal abscess formation. $J$. Infect. Dis. 136: 789-795.

10. Kabat, E. A., and Mayer, M. M. 1961. Experimental Immunochemistry. Charles $\mathrm{C}$ Thomas, Publisher, Springfield, 2nd edition. 763-764.

11. Julius, M. H., E. Simpson, and L. A. Herzenberg. 1973. A rapid method for the isolation of functional thymusderived murine lymphocytes. Eur. J. Immunol. 3: 645649.

12. Holdeman, L. V., E. P. Cato, and W. E. C. Moor. 1977. Anaerobe Laboratory Manual. Virginia Polytechnic Institute Anaerobe Laboratory, Virginia Polytechnic Institute and State University, Blacksburgh, Va. 4th edition. 145 .

13. Armitage, P. 1971. Statistical Methods in Medical Re- search. John Wiley \& Sons, Inc., New York. lst edition. 362-393.

14. Hill, A. B. 1971. Principles of Medical Statistics. Oxford University Press, Inc., New York. 9th edition. 390.

15. Lefford, M. J. 1975. Delayed hypersensitivity and immunity in tuberculosis. Am. Rev. Respir. Dis. 111: 243246.

16. Youmans, G. P. 1975. Relationship between delayed hypersensitivity and immunity in tuberculosis. Am. Rev. Respir. Dis. 111: 109-118.

17. Mackaness, G. B., and W. C. Hill. 1969. Effect of antilymphocyte globulin in cell-mediated resistance to infection. J. Exp. Med. 129: 993-1012.

18. Blanden, R. W., and R. E. Langman. 1972. Cell-mediated immunity to bacterial infection in the mouse. Thymus-derived cells as effectors of acquired resistance to Listeria monocytogenes. Scand. J. Immunol. 1: 379.

19. Taubler, J. G. 1968. Staphylococcal delayed hypersensitivity in mice. I. Introduction and in vivo demonstration of delayed hypersensitivity. J. Immunol. 101: 546549.

20. Gorbach, S. L., and J. G. Bartlett. 1974. Anaerobic infections. N. Engl. J. Med. 290: 1177-1184.

21. Kasper, D. L., M. E. Hayes, B. G. Reinap, F. O. Craft, A. B. Onderdonk, and B. F. Polk. 1973. Isolation and identification of encapsulated strains of Bacteroides fragilis. J. Infect. Dis. 136: 75-81.

22. Fisher, M. D., H. G. Baluarte, and S. S. Long. 1981. Bacteremia due to Bacteroides fragilis after elective appendectomy in renal transplant recipients. J. Infect. Dis. 143: 635-638.

23. Crowle, A. G., and C. C. Hu. 1967. Delayed hypersensitivity in mice to dextran. Int. Arch. Allergy Appl. Immunol. 31: 123-144.

24. Battisto, J. R., G. Chappetta, and R. Hixon. 1968. Immunologic responses of guinea pigs to dextran. J. Immunol. 101: 203-209.

25. Gerety, R. J., R. W. Ferraresi, and S. Raffel. 1970. Polysaccharide in delayed hypersensitivity. I. Pneumococcal polysaccharide as inducer and elicitor of delayed reactivity in guinea pigs. J. Exp. Med. 131: 189-206. 